\title{
ASPEK HUKUM PERBANKAN SYARIAH DAN IMPLEMENTASINYA DI INDONESIA
}

\author{
H. M. Ali Mansyur \\ Fakultas Hukum Universitas Islam Sultan Agung Semarang
}

\begin{abstract}
Legal Aspects of Sharia Banking Legislation, Law Number 21 of 2008, in terms of judicial philosophy and Sociological basically a sense of Justice has addressed the needs of the Islamic Ummah as a consequence of legal pluralism live and grow in the dynamics of Indonesian society. While from the juridical formalistic approach through the legal umbrella Act No.3 of 2006 and Act No. 4 of 2004 its implementation requires a judge in creating and upholding justice, should know and understand the aspirations and values of living in society and orientation, which should put forward justice together with the orientation of legal certainty and expediency.
\end{abstract}

Keywords: shariah banking, implementation

\begin{abstract}
Abstrak
Aspek Hukum Undang-undang Perbankan Syariah UU No. 21 Tahun 2008, dilihat dari sisi filosofi yuridis dan Sosiologis pada dasarnya telah menjawab kebutuhan rasa Keadilan Ummat Islam sebagai konsekuensi fluralisme hukum yang hidup dan tumbuh dalam dinamika masyarakat Indonesia. Sedangkan dari pendekatan yuridis formalistik melalui payung hukum UU No.3 tahun 2006 dan UU No.4 tahun 2004 implementasinya menuntut hakim dalam mewujudkan dan menegakkan keadilan, hendaknya mengetahui dan memahami aspirasi serta nilai-nilai yang hidup dalam masyarakat dan orientasi, keadilanlah yang harus dikedepankan bersama-sama dengan orientasi kepastian hukum dan kemanfaatan.
\end{abstract}

Kata kunci : perbankan syariah, implementasi

\section{Pendahuluan}

Islam sebagai agama samawi mengatur hidup manusia dalam 2 (dua) dimensi hidup secara seimbang (Islam is be dimensional) antara aspek dunia dan akhirat, lahir dan batin. Pengaturan dari masing-masing dimensi tersebut untuk mengantarkan pada tujuan (finnal arrow) harus didukung ilmu (science), usaha (movement) dan Iman (faith). Dalam kaitan dengan persoalan ekonomi, tentu perangkat alat dan metode yang harus dimiliki adalah ilmu ekonomi, mekanisme berekonomi dan tujuan usaha tersebut.

Lembaga perbankan merupakan inti dari sistem keuangan di setiap negara, karena bank merupakan rujukan setiap orang, badan usaha, baik swasta maupun milik negara/pemerintah, untuk melakukan transaksi baik dalam bentuk penyimpanan uang, hutang piutang, serta jasa- jasa lainnya yang berhubungan dengan masalah keuangan. ${ }^{1}$

Perbankan yang merupakan salah satu pilar ekonomi merupakan perwujudan dari nilai Islam terutama pada wilayah "muamalah-syariah al Umumiyyah", dimana persoalan ekonomi berada pada ranah publik, manusia diberikan kebebasan untuk menyusun konsep, mengatur dan menjalankan sendiri sepanjang tidak bertentangan dengan ketentuan syariat Islam. Rasul bersabda "Antum a'lamu bi ummuriddunyakum" (kamu lebih mengetahui urusan duniamu). Firman Allah SWT: "Sesungguhnya usaha manusia itu macam-macam" (QS. Al-Lail: 595).

Berdasarkan ketentuan tersebut di atas, apabila dalam kehidupan ini lahir berbagai kon-

Suwandi, "Pembangunan Hukum Perbankan Syariah di Indonesia, Jurnal Hukum Islam El Qisth Vol. 3 No. 2, Maret 2007, hlm. 211 
sep/ideologi ekonomi tentu ini merupakan antitesanya, diantaranya ekonomi kapitalis, ekonomi sosialis, ekonomi koperasi dan ekonomi Islam (ekonomi syariah), walaupun diantara berbagai sistem-sistem tersebut tidak semua mendapatkan ridho Allah SWT, jika implikasinya bertentangan dengan ketentuan Syariah².

Berangkat dari kenyataan tersebut, sejarah telah membuktikan bahwa sistem ekonomi Islam tahan banting menghadapi goncangan ganasnya zaman. Sementara sistem konvensional/kapitalis/sosialis mudah jatuh bangun terhimpit oleh badai krisis yang berkepanjangan dan silih berganti. Namun demikian, di Indonesia sistem ekonomi Islam (perbankan Islam) secara jujur belum menjadi primadona di kalangan umat sendiri.

Indonesia sejak tahun 1992 telah mulai berdiri perbankan syariah yang dipelopori BMI (Bank Muamalat Indonesia), selanjutnya berkembang dengan pesat tahun 2009 telah berdiri 1440 kantor Bank Syariah, belum termasuk bank konvensional yang membuka unit usaha syariah. ${ }^{3}$ Karakteristik sistem perbankan Islam yang beroperasai berdasarkan prinsip bagi hasil (mudharabah) diharapkan mampu memberikan alternatif sistem perbankan yang saling menguntungkan bagi masyarakat dan bank, serta menonjolkan aspek keadilan dalam bertransaksi, investasi yang beretika, mengedepankan nilai-nilai kebersamaan, persaudaraan dalam berproduksi dan menghindari kegiatan spekulatif dalam bertransaksi keuangan. Dengan menyediakan beragam produk serta layanan jasa perbankan yang beragam diharapkan perbankan syariah menjadi alternatif sistem perbankan yang kredibel dan dapat diminati oleh seluruh golongan masyarakat Indonesia tanpa kecuali.

2 Muh. Shohibul Itmam, "Mengurai Pemikiran islam Dalam Perspektif Sunny dan Syi'ah, Antara Persamaan dan Perbedaan", Addin Vol. 2 No. 1, Januari-Juni 2008, $\mathrm{hlm}$. 52; lihat juga Erine Pane, "Reksadana Syariah dalam Perspektif Hukum ekonomi", Jurnal kajian Hukum Al Adalah Vol. 7 No. 2, Desember 2008

3 Lihat Mawardi Muzamil, "Persamaan Perkreditan Perbankan Konvensional dan Pembiayaan Perbankan Syariah”, Jurnal Hukum Vol. 15 No. 3, April 2004, hlm. 515; lihat jugaErnawati, "Perbankan Syariah Dalam Tata Hukum Ekonomi Indonesia”, Bilancia Vol. 2 No. 1 Januari-Juni 2008, hlm. 79
Namun kenyataannya sebagian besar penduduk Indonesia yang beragama Islam lebih condong menginvestasikan hartanya ke bank konvensional (belum ke bank syariah), dikarenakan adanya asumsi bank konvensional lebih aman dan mudah dalam melakukan transaksi dibanding bank syariah (anggapan umum). Menyikapi kenyataan yang ada tersebut perlu diadakan langkah-langkah preventif maupun kuratif untuk mengemba-likan kemuliaan misi bank syariah, meskipun disana-sini masih ada kekurangannya.

Perkembangan bisnis syariah di Indonesia tidak terlepas dari perkembangan bisnis syariah pada masyarakat negara-negara Islam di dunia. Tentu kenyataan tersebut berpengaruh terhadap hiruk-pikuk perbankan syariah. Prinsipprinsip dasar ekonomi syariah yang selama ini kita kenal melalui bank syariah adalah nilainilai etika dan norma ekonomi yang universal dan komprehensif. ${ }^{4}$ Keuniversalan itu sengaja diberikan pada umat untuk memberikan kesempatan agar ber-inovasi (ijtihad) dan berkreasi (jihad) dalam mengatur sistem ekonominya dengan syarat tidak keluar dari kerangka umumnya. Dengan demikian sistem ekonomi Islam akan valid dan cocok untuk setiap perubahan waktu dan perbedaan tempat dan umat Islam mampu memerankan fungsinya sebagai kholifah di muka bumi ini.

Berdirinya Perbankan dengan sistem syariah Islam dengan landasan yuridis formal Undang-Undang No. 21 Tahun 2008 tentang Perbankan Syariah. Undang-undang tersebut secara implisif membuka peluang kegiatan "bagi hasil" dan lahirnya Undang-Undang Perbankan Syariah ini diharapkan mampu merangsang masuknya investor asing ke Indonesia.

Secara garis besar hubungan antara bank dengan nasabah dapat dilihat dari klausula yang ada dalam akad yang terdiri dari 5 (lima) konsep akad, yaitu sistem simpanan murni, sistem

Diana Wiyanti, "Pasar Modal Syariah dalam Kajian Hukum Bisnis", Jurnal Kajian Hukum al Adalah, Vol. 7 No. 2, Desember 2008, hlm. 111, lihat juga Abdul Mughits, "Kompilasi Hukum Ekonomi Syariah (KHES) dalam Tinjauan Hukum Islam", Al-Mawarid Edisi XVIII Tahun 2008, hlm. 146-149 
bagi hasil, sistem jual beli dengan marjin keuntungan, sistem sewa dan sistem fee (jasa)

Upaya mewujudkan 5 (lima) konsep akad tersebut, lembaga keuangan syariah harus memperhatikan larangan-larangan dalam Islam. Akad-akad tradisional Islam sebagai alternatif dan implementasinya dalam tran-saksi-transaksi LKS (Lembaga Keuangan Syariah), Kelayaan usaha bank, dan lain-lain. Di sisi lain juga harus memperhatikan hal-hal yang terkait dengan keadaan dari debitur (nasabah) yang menyangkut 5C (the five C for credit), diantaranya character, capital, capacity, collateral, and condition of economy.

Berangkat dari uraian di atas, munculnya permasalahan dalam transaksi ekonomi syariah, lebih banyak terjadi karena ketidak disiplinan dari para fihak. Dalam bahasa lain terdapat ketidakberesan dalam pelaksanaan isi perjanjian. Selanjutnya tentu ada fihak-fihak yang dirugikan dan kemudian muncul sengketa/konflik diantara para fihak. Selanjutnya konflik tersebut harus diselesaikan sesuai dengan koridor hukum yang ada. Berdasarkan latar belakang tersebut, penulis tertarik untuk membahas mengenai implementasi filosofis, yuridis dan sosiologis perbankan syariah sebagai pranata hokum ekonomi di Indonesia.

\section{Pembahasan}

\section{Aspek Filosofis Undang-undang Perbankan Syariah}

Undang-undang Nomor 21 Tahun 2008 tentang Perbankan Syariah (UUPS), keberadaannya sesungguhnya merupakan tuntutan untuk memenuhi ketentuan Pasal 49 Undang-Undang No. 3 Tahun 2006 Tentang Peradilan Agama, khususnya perubahan lembaga peradilan agama menyangkut (kompetensi) yang harus diemban oleh peradilan agama dalam memenuhi amanat Undang-undang. Apabila dirunut dari aspek historis eksistensi Peradilan Agama sudah ada sejak zaman penjajah sampai kemerdekaan, hingga sekarang reformasi tidak dipersoalkan lagi, ${ }^{5}$ hanya saja yang menjadi persoalan meng-

Andi Akram, "Sejarah Peradilan Agama di Indonesia", Al Manahij Vol. 2 No. 1, Januari-Juni 2008, hlm. 104105 apa kewenangan pengadilan agama yang telah mempunyai status sama kedudukannya dengan peradilan yang lain, namun kompetensi mengadili perkara bagi orang Islam belum semua dapat dilaksanakan oleh Peradilan Agama, artinya masih terjadi tarik menarik dengan peradilan yang lain, padahal masing-masing telah mempunyai kompetensi sendiri-sendiri.

Peradilan Agama dengan Undang-undang No. 3 Tahun 2006 mempunyai kewenangan untuk menyelesaikan perkara bagi umat Islam (orang yang beragama Islam) meliputi hukum keluarga (Nikah, Waris, Zakat) dan ekonomi syariah mencakup bank syariah, lembaga keuangan mikro syariah, reksadana syariah, obligasi syariah, asuransi syariah, reasuransi syariah, surat berjangka menengah syariah, Securitas syariah, Pegadaian syariah, DPLK syariah, dan bisnis syariah.

Kewenangan absolut dari Peradilan Agama yang ada sekarang apabila dilihat aspek filosofis menunjukan bahwa perkembangan kebutuhan hukum masyarakat (muslim khususnya) terhadap kesadaran menjalankan syariat Islam sebagai konsekuensi dari keyakinannya semakin tinggi. Ini berarti bahwa pluralisme hukum harus diterima sebagai realitas (Real of Entity) yang majemuk (legal fluraly) dalam kehidupan bermasya-rakat, sebagaimana diungkapkan oleh Cotterral: 1995 "We should think of law as a phenomenon pluralistically, as a regulation of many krud existing in a veriety of relationships, same of the quit tenuous, with the primary legal institutions of the centralized state".

Pendapat di atas menjelaskan bahwa hukum yang berlaku dalam masyarakat selain terwujud dalam bentuk peraturan perundangundangan (order of law) dan hukum kebiasaan (costumary law) secara antropologis membentuk mekanisme-mekanisme pengaturan sendiri (inner order machanism atau self regulation) dalam komunitas-komunitas masyarakat adalah merupakan hukum yang secara lokal berfungsi sebagai sarana menjaga keteraturan dan ketertiban sosisal. Hukum adalah institusi yang dinamis dan mengalir, hukum dibuat untuk manusia, bukan manusia untuk hukum, antara 
hukum dan manusia direalisasikan dalam masyarakat yang menjadi tempat berinteraksi. Ketiga ordinat (hukum, manusia dan masyarakat) yang menyebabkan hukum menjadi institusi yang dinamis. Perubahan/pergeseran hukum secara pelan-pelan terjadi dari " the law ways" menuju "the sociological ways" kemudian kepada "the sociological movement in law (hunt), atau "the sociological era". 6

Eksistensi Undang-undang Peradilan Agama UU Nomor 3 Tahun 2006, Undang-undang Perkawinan Nomor 1 Tahun 1974, UU Nomor 38 Tahun 1999 Tentang Pengelolaan Zakat, Inpres Nomor 1 Tahun 1991 Tentang KHI dan sekarang RUU Perbankan Syariah, tidak dapat dilepaskan dari historis (sejarah), artinya lahirnya institusi di atas bukan institusi yang "a historis" melainkan "historisch bepaald". Artinya munculnya dinamika hukum itu tidak dapt melepaskan /menyembunyikan dinamika sosial dibelakangnya. Hukum tumbuh, berkembang dan ambruk disebabkan oleh dinamika dalam masyarakat Polarisasi kewenangan Peradilan Agama mengadili perkara sengketa perbankan syariah/perbankan Islam, yang dalam Undang-Undang Perbankan Syariah pada Pasal 52 jika dilihat dari aspek filosofis yuridis pada dasarnya menjawab kebutuhan rasa keadilan Umat Islam sebagai konsekuensi fluralisme hukum yang hidup dan tumbuh. Karenanya penyerahan Penyelesaian Perkara bisnis Syariah ke Peradilan Umum/ Pengadilan Negeri dirasa kurang memenuhi rasa keadilan (kontradiktoris value) dan bertentangan dengan prinsip historycal bepaald yang telah terjadi selama ini, karena itu penyelesaian sengketa perkara perbankan Islam harus diserahkan kepada Pengadilan Agama.

\section{Aspek Yuridis Perbankan Syariah}

Peradilan Agama, secara yuridis normatif merupakan amanat konstitusi Undang-undang NKRI 1945 Pasal 24, Pasal 25, yang konkritisasi formalitasnya Undang-Undang Nomor 3 Tahun 2006 dan dipayungi oleh Undang-Undang Nomor 48 Tahun 2009 tentang Kekuasaan Kehakiman.

Sajipto Rahardjo, 2007, Menggagas Hukum Progresif, Semarang : Pustaka Pelajar dan IAIN Walisongo, hlm. 16.
Undang-undang perbankan syariah, jika diteropong dari aspek yuridis merupakan hukum yang baik, karena hukum yang baik adalah hukum yang mempunyai kekuatan yuridis yang memberikan kepastian hukum. Dalam rangka mewujudkan kepastian hukum unsur penegakan hukum dari Friedman (substansi,struktur dan kultur) penekanan unsur manusia merupakan pelaku utama dalam segala kegiatan untuk mewujudkan keadilan.

Pendekatan hukum yang bersifat empirikpossitivistik tidak cukup untuk mewujudkan keadilan, tetapi proses interaksi antara manusia dengan lingkungan yang dilandasi dengan budaya akan lebih menjadi bermakna. Dalam hal ini maka pemahaman hukum melalui pengalaman internal para subyek pelaku dan hukum merupakan makna mereka. Berdasarkan pemahaman (verstehen) dan interpretasi, kita dapat menangkap makna, nilai-nilai dibalik perilaku mereka. Karenanya kajian yang digunakan bukan lagi semata-mata yuridis dogmatik melainkan pendekatan sosio legal-antro yang diorientasi pada fungsionalisasi hukum.

Undang-undang Nomor 21 Tahun 2008 dilihat dari pendekatan yuridis formalistik dengan payung hukum (UU No. 3 Tahun 2006, UU No. 4 Tahun 2004) tentu pemahaman hukum dalam konteks kehidupan masyarakat Indonesia yang sedang berubah, lalu lintas kebutuhan yang semakin beragam dan kompleks merupakan realitas tuntutan kebutuhan hukum dan hukum bukan sekedar untuk menjadi bahan pengkajian secara logis rasional melainkan hukum dibuat untuk dijalankan. Perwujudan tujuan, nilai-nilai ataupun ide-ide yang terkandung dalam peraturan hukum merupakan suatu kegiatan yang tidak berdiri sendiri, melainkan mem-punyai hubungan timbal balik yang erat dengan masyarakat. ${ }^{7}$

Rancang bangun berfikir menyamaratakan penyelesaian sengketa perbankan syariah dengan non syariah dapat mengakibatkan hukum menjadi disorder of law, karena kompetensi absolut ekonomi syariah berada di Peradilan Agama beserta perangkat hukumnya,

Ibid, hlm. 10. 
yang syarat dengan nilai, azas dan ide serta tujuan yang sudah jelas. Jika kemudian penerapannya tidak pas, artinya tidak berasal atau ditumbuhkan dari kandungan masyarakat akan merupakan masalah, karena terjadi ketidakcocokan, antara nilai-nilai yang men-jadi pendukung sistem hukum yang bersangkutan dengan nilai-nilai yang dihayati oleh anggota masyarakat itu sendiri. Untuk itu penyelesaian sengketa perbankan syariah oleh Pengadilan Umum bertentangan dengan pemahaman hukum "yuridis sosiologis antropologis". Dengan demikian sangat relevan kalau penyelesaian sengketa ekonomi syariah adalah di Pengadilan Agama.

Persoalan keadilan merupakan masalah yang tidak pernah akan selesai secara tuntas dibicarakan orang, bahkan akan makin mencuat seiring dengan perkembangan masyarakat itu sendiri. Keadilan bukan sesuatu yang dapat diperoleh hanya melalui penalaran atau logika saja melainkan melibatkan perilaku seseorang secara utuh. ${ }^{8}$ Hukum memiliki dimensi nilainilai etika moral yang terwujud dalam azasazas hukum dan tertuang dalam norma-norma serta terumuskan dalam aturan-aturan. Oleh sebab itu, seorang hakim dalam menjalankan tugasnya mencari kebenaran untuk menentukan kesalahan seseorang tidak cukup hanya memakai landasan yuridis semata tetapi juga landasan filosofis dan sosiologis.

Aturan normatif materiil dalam rangka untuk menyelesaikan perkara dibidang ekonomi syariah belum ada. Hal ini akan berdampak pada kemungkinan terjadinya disparitas putusan dalam menyelesaikan perkara ekonomi syariah di Pengadilan Agama. Belum adanya aturan hukum materiil dapat mengakibatkan kurangnya kepastian hukum sebagai akibat dari perbedaan pegangan bagi hakim dalam menyelesaikan perkara ekonomi syariah. Oleh karena itu, peran dan fungsi hakim diharapkan memiliki kemampuan menterjemahkan nilainilai keadilan dalam persoalan yang dihadapkan kepadanya melalui keputusan-keputusannya.

Ibid, hlm. 14.
Hakim dalam mencari dan menegakkan kebenaran atas dasar landasan yuridis, hendaknya memiliki landasan kebenaran dan keadilan berdasarkan Ketuhanan Yang Maha Esa, mengetahui dan memahami aspirasi serta nilainilai yang hidup dalam masyarakat. Apa yang diungkapkan di atas mendasari lahirnya Undang-undang Perbankan Syariah, artinya nilainilai yang hidup dalam masyarakat muslim tereduksi dalam Undang-undang Perbankan Syariah yang sudah diundangkan.

\section{Implementasi Sosiologis Perbankan Syariah}

Berdasarkan aspek politik hukum lahirnya Undang-undang Perbankan Syariah Nomor 21 Tahun 2008, masih menyisakan pekerjaan rumah di antaranya tahap yuridis, tahap kelembagaan dan tahap mekanik. Tahap yuridis, memfokuskan pada bagaimana hukum yang tertulis (legal formal) dapat berjalan, ditegakan di tengah-tengah masyarakat untuk mencapai keadilan. Tentu aspek penegak hukum yang oleh Friedman dipengaruhi oleh sub sistem substansi, struktur dan kultur yang akan menjawab efektif tidaknya suatu perundang-undangan. Oleh karena itu dalam tahap ini ada kaitan erat dengan asas-asas hukum yang lazim kita kenal dengan istilah nilai dasar hukum yaitu: kemanfaatan, keadilan dan kepastian hukum (Gustave Radbruch).

Tahap kelembagaan, mempertanyakan sejauh mana kesiapan lembaga Peradilan Agama dalam menjalankan ketentuan Undangundang Perbankan Syariah, sebagai aparat penegak hukum yang memperoleh kepercayaan masyarakat, tentu dalam hal ini harus ada dukungan dari political will untuk mensosialisasikan Undang-Undang Nomor 21 Tahun 2008, melalui pemberdayaan masyarakat dengan meningkatkan komunikasi hukum, pemahaman hukum dan kebijakan pemerintah.

Tahap mekanik, mengupayakan langkahlangkah bagaimana implementasi hukum UU No. 21 Tahun 2008 dapat memenuhi kebutuhan masyarakat, perlu diupayakan penyempurnaan perangkat hukum materiil maupun hukum formil, sehingga upaya penegak hukum tidak berhenti sampai pada pengundangan UU No. 21 
Tahun 2008 saja, namun belum mampu memberikan andil dalam penyelesaian kasus-kasus ekonomi syariah, yang disebabkan oleh belum berjalannya sistem Pengadilan Agama khusus mengenai ekonomi syariah.

Hukum dalam menjalankan fungsinya sebagai pengatur kehidupan bersama manusia harus menjalani sebuah proses yang panjang dan melibatkan berbagai aktivitas dengan kualitas yang berbeda-beda. Hukum harus diturunkan dari dimensi abstrak ke dimensi konkrit, dalam hal ini UU No. 21 Tahun 2008 agar keberadaannya dapat dirasakan oleh masyarakat (the orientation of political law).

Pada tataran proses membutuhkan orientasi hukum (orientation of the law) yang mengarah pada aspek manusianya sebagai subyek hukum (pembudayaan personal/personal attitudes) yang akan menentukan berjalan atau tidaknya ketentuan formal No. 21 Tahun 2008 tersebut. Sehingga diperlukan langkah yang mencakup "mekanik action plan", berupa juklak dan juknis serta Human action planning model berupa daya keahlian dari aparat penegak hukum untuk mengembangkan hukum menuju hukum yang responsif dan progresif.

Di samping itu juga, penting dan mendesak untuk dibangun konstruksi hukum (construction of the (aw) yang menjadi perangkat hukum yang menjadi norma hukum material yang dijadikan rujukan hakim dalam memutuskan suatu perkara (tentu dalam bentuk UU atau peraturan pemerintah), maupun hukum formal yang merupakan hukum acara, menjadi alat bagi hakim dalam mene-gakkan hukum material.

\section{Paradigma Penyelesaian Sengketa Transaksi Ekonomi Syariah}

Terdapat tiga fungsi dalam konsep negara modern, yaitu membuat efisiensi, memeratakan pendapatan dan meningkatkan pertumbuhan ekonomi. Hal tersebut dapat dilakukan melalui pembentukan kebijakan dan penegakan hukum yang mendukung fungsi tersebut. ${ }^{9}$

Diana Halim Koentjoro, "Penegakan Hukum dan Pertumbuhan Ekonomi di Indonesia", Gloria Juris Vol. 6 No. 2, Mei-Agustus 2006, hlm 164
Penyelesaian sengketa utamanya menyangkut persoalan perdata (perjanjian) karena sesungguhnya lebih luwes dibandingkan persoalan pidana, karena dengan dianutnya faham/atas terbuka (kebebasan berkontrak) di mana para pihak bebas membuat perjanjian apapun bentuk dan isinya sepanjang tidak di larang oleh UU, tidak bertentangan dengan kesusilaan dan ketertiban umum. Penerapan azas ini berlaku juga jika dikemudian hari terjadi sengketa/masalah para pihak dapat mencari alternatif pemyelesaian sendiri berdasarkan kesepakatan kedua belah pihak.

Pilihan penyelesaian sengketa perdata selama ini dipakai metode penyelesaian yang bersifat litigasi (peradilan) dan non litigasi (penyelesaian di luar pengadilan). Memang kata akhir dari penyelesaian sengketa perdata yang tidak dapat diselesaikan melaului jalur non peradilan, pengadilan harus dapat menyelesaikan demi mewujudkan keadilan, kemanfaatan dan kepastian hukum. Artinya pengadilan tidak boleh menolak untuk mengadili setiap perkara yang diajukan kepadanya (the first and last resort).

Rumusan yang kita tulis pada baris terakhir ini ternyata sekarang masih dipandang oleh sebagian kalangan penyelesaian melalui pengadilan hanya menghasilkan kesepakatan yang bersifat adversarial, belun mampu merangkum kepentingan bersama, cenderung menimbulkan masalah baru, lambat dan lama penyelesaiannya, membutuhkan biaya yang mahal, tidak responsive, dan banyak pelanggaran dalam pelaksanaannya. Hal ini, dipandang kurang menguntungkan dalam dunia bisnis, sehingga dibutuhkan institusi baru yang dipandang lebih efisien dan efektif.

Seiring dengan perkembangan lahirlah penyelesaian sengketa yang bersifat "non litigasi" yang dianggap lebih bisa meng-akomodasi kelemahan model litigasi dan memberikan jalan keluar yang lebih baik. Penyelesaian dengan pola win-win solution, menjamin kerahasiaan para pihak yang bersengketa, menyelesaikan persoalan secara komperehensif dalam kebersamaan dan tetap menjaga hubungan baik. 
Berangkat dari paradigma penyelesaian sengketa transaksi ekonomi di atas, orientasi penyelesaian sengketa ekonomi syariah dengan berpijak pada landasan formal yuridis yang ada di Indonesia antaranya, Pertama, UU No. 10 Tahun 1998 Tentang Perbankan utamanya Pasal 1 No. 12 disebut: pembiayaan berdasar-kan syariah, Pasal 1 angka 13 disebut prinsip syariah, Pasal 6, Pasal 8, Pasal 10, Pasal 11 dan Pasal 13 (c); Kedua, UU No. 3 Tahun 2004 Tentang Bank Indonesia, Ketiga, UU No. 3 Tahun 2006 Tentang One Roof Sytem Peradilan Agama dibawah MA, Keempat, UU No. 21 Tahun 2008 Tentang Perbankan Syariah, yang menjawab ketentuan Pasal 49 UU No. 3 Tahun 2006, menyatakan Pengadilan Agama bertugas dan berwenang, memeriksa, memutus, dan menyelesaikan perkara tingkat pertama antara orang-orang beragama Islam di bidang: perkawinan, warisan, wasiat, hibah, wakaf, zakat, infak, shodakah,ekonomi syariah; Kelima, UU. No. 30 tahun 1999 Tentang Arbitrase dan alternatif penyelesaian sengketa; Keenam, SEMA No. 10 Tahun 2010 Tentang Pedoman Pemberian Bantuan Hukum

Penyelesaian sengketa ekonomi syariah di Indonesia melalui proses ajudifikasi dilakukan melalui 2 (dua) lembaga formal yang di bentuk yaitu BASYARNAS (Badan Arbitrase Syariah) dan Peradilan Agama (PA) sesuai dengan ketentuan UU. No.3 Tahun 2006 Pasal 49. Perkembangan ekonomi syariah, melalui UU No 3 Tahun 2006 Bangsa Indonesia telah sepakat, apabila terjadi sengketa berkaitan dengan ekonomi (bisnis) syariah, akan diselesaikan melalui Pengadilan Agama. Di dalam praktek tidak mutlak harus melalui jalur pengadilan, karena tradisi hukum positif yang berlaku dalam masyarakat, penyelesaian sengketa seoptimal mungkin harus ditempuh upaya perdamaian/ mediasi (SEMA No. 1 Tahun 2008), bahkan hal ini sangat dianjurkan, meskipun masyarakat percaya keadilan itu mempunyai hak dan kebebasan untuk menentukan sikapnya dan memilih lembaga mana yang akan digunakan untuk memenuhi kepentingannya (choice of alternatif justice).

\section{Faktor-faktor yang Mempengaruhi Penegak Hukum Ekonomi Syariah}

Keberadaan Lembaga Peradilan Agama yang diberikan kewenangan untuk mengadili perkara/sengketa ekonomi (bisnis) syariah berdasarkan UU No. 3 Tahun 2006 jo. UU No. 21 Tahun 2008 merupakan perwujudan tanggung jawab dan keniscayaan. Perubahan demi perubahan pada tataran pranata maupun lembaga menunjukan bahwa hukum sesungguhnya merupakan institusi dinamis dan mengalir, hukum dibuat oleh manusia untuk manusia (muamalah oriented), dan berlaku juga untuk masyarakat. Karenanya perubahan tersebut hendaknya juga diikuti perubahan pada bagian yang lain, meliputi, Pertama, penyelesaian sengketa perbankan syariah harus ditangani oleh Pengadilan Agama dan Basyarnas bukan Pengadilan Umum; Kedua, seluruh hakim Peradilan Agama harus memahami hukum-hukum perbankan dan lembaga keuangan syariah lainnya; Ketiga, undang-undang organik lainnya yang ada kaitan langsung dengan UU No. 3 Tahun 2006 harus menyesuaikan (diamandemen), diantara-nya UU Arbitrase, UU Pasar Modal, UU Asuransi, UU Pegadaian, UU lainnya; dan Keempat, perlu penambahan/perubahan materi Kompilasi Hukum Islam dengan menambah hukum eko-nomi syariah.

Beberapa faktor yang mempengaruhi upaya penegakan UU No. 21 Tahun 2008 di antaranya: kurangnya sumber daya manusia (SDM); aspek yuridis (perlunya UU materiil yang menjadi sumber rujukan); Kelembagaan, perlu perombakan yang cukup mendasar baik struktur, karir hakim dan lain-lain yang berkaitan dengan penguatan kelembagaan; aspek pemberdayaan masyarakat (pemahaman masyarakat tentang ekonomi syariah); aspek penciptaan mekanisme penyelesaian sengketa perbankan syariah; belum adanya standar dalam penerapan prinsip syariah dalam memecahkan masalah perbankan syariah; sentralisasi kebijakan dan kurangnya infrastruktur. ${ }^{10}$

10 M. Ali Mansyur, 2009, Implementasi Prinsip Perbankan Syariah Menurut UU No. 21 Tahun 2008 dalam Operasional Perbankan Syariah di Indonesia, Laporan Pene- 
Penegakan hukum tidak bisa diserahkan kepada aparat penegak hukum saja, namun tentunya harus didukung oleh semua pihak. Dalam realitanya tidaklah semudah yang kita bayangkan. Banyak sekali tantangan-tantangan yang harus dihadapi. Secara umum tantangan yang paling terberat adalah manusia, karena manusia diberi akal dan nafsu sehingga menjadikan mereka lebih cenderung memuaskan keinginan pribadi. Namun demikian, perlu diperhatikan pula bahwa keberhasilan hukum dalam memainkan peranan dalam pembangunan ekonomi, seperti di negara-negara maju, justru tidak sesederhana yang dialami oleh negara berkembang. Hal ini disebabkan masih kuatnya isu-isu klasik seperti rendahnya tingkat kesejahteraan dan pendidikan. ${ }^{11}$

Tantangan yang lain meliputi tantangan struktural, yang terdiri dari struktur masyarakat maupun struktur aparat, masyarakat dan aparat yang membangun budaya hukum untuk mentaati atau melanggar hukum. Kemudian tantangan formal, dalam hal pendekatan penyelesaian kasus hukum yang berorientasi pada konsep "formal Justice" semata tanpa memperdulikan Substansial Justice, tidak akan pernah tercapai tujuan hukum yang sesungguhnya. ${ }^{12}$ Penegakan hukum Undang-undang No.21 tahun 2008 yang telah dimulai saat ini dan seterusnya, kendalanya memperhatikan tantangan-tantangan yang ada secara cermat, karena akan sangat berpengaruh terhadap keberhasilan penegak hukum itu sendiri.

\section{Penutup}

\section{Simpulan}

Undang-undang Perbankan Syariah No. 21 Tahun 2008 secara filosofi yuridis telah memenuhi tuntutan rasa keadilan dan kepastian hukum pencari keadilan, terutama menyangkut transaksi bisnis ekonomi syariah. Pada tataran politik hukum eksistensi UU No. 21 tahun 2008

litian Pasca Sarjana Magister (S-2) Ilmu Hukum UNISSULA, hlm. 79.

11 Taufik H Simatupang, "Hukum dan Pembangunan Ekonomi”, Jurnal Ilmiah Kebijakan Hukum, Vol. 1 No. 1, April 2007, hlm. 20

12 M. Ali Mansyur, 2010, Pranata Hukum dan Penegakan Hukum di Indonesia, UNISSULA-PRESS, Semarang, hlm. 123. masih menyisakan pekerjaan rumah diantaranya tahap yuridis, tahap kelembagaan dan tahap mekanik.

Implementasi penyelesaian sengketa ekonomi bisnis syariah menurut pasal 52 diserahkan kepada Pengadilan Agama adalah sangat relevan dengan kewenangan absolut yang diberikan oleh Undang-Undang No.3 tahun 2006 jo UU No. 4 tahun 2004. Faktor-faktor yang mempengaruhi penegakan hukum Undang-undang perbankan syariah antara lain menyangkut kurangnya sumber daya manusia (SDM), kelembagaan, pemberdayaan masyarakat, penciptaan mekanisme penyelesaian sengketa, standard penetapan prinsip syariah dalam memecahkan masalah, kebijakan dan kurangnya infrastruktur, kesemuanya akan terpenuhi apa tidak tergantung dari kesungguhan dari pengambil kebijakan (parti-cal will), dalam merespon persoalan ekonomi bisnis syariah itu sendiri.

\section{Saran}

Upaya untuk mewujudkan perundangundangan perbankan syariah sebagai pranata hukum, maka perlu dukungan kelembagaan (struktur hukum) dan budaya hukum masyarakat (culture hukum), sehingga penerimaan norma perbankan syariah secara filosofis, yuridis dan sosiologis dapat dilakukan, selain itu juga perlu sosialisasi perundang-undangan perbankan syariah agar lebih aplikatif dalam penerapannya di masyarakat.

\section{Daftar Pustaka}

Akram, Andi. "Sejarah Peradilan Agama di Indonesia". Al Manahij. Vol. 2 No. 1. Januari-Juni 2008;

Ernawati. "Perbankan Syariah Dalam Tata Hukum Ekonomi Indonesia". Bilancia. Vol. 2 No. 1 Januari-Juni 2008;

Itmam, Muh. Shohibul. "Mengurai Pemikiran Islam Dalam Perspektif Sunny dan Syi'ah, Antara Persamaan dan Perbedaan". Addin. Vol. 2 No. 1. Januari-Juni 2008;

Koentjoro, Diana Halim. "Penegakan Hukum dan Pertumbuhan Ekonomi di Indonesia". Gloria Juris. Vol. 6 No. 2. MeiAgustus 2006; 
Mansyur, M Ali 2009. “Implementasi Prinsip Perbankan Syariah Menurut UU No. 21 Tahun 2008 dalam Operasional Perbankan Syariah di Indonesia". Laporan Penelitian Pasca Sarjana Magister (S-2) IImu Hukum UNISSULA;

-2010. Pranata Hukum dan Penegakan Hukum di Indonesia. Semarang: UNISSULA-PRESS;

Mughits, Abdul. "Kompilasi Hukum Ekonomi Syariah (KHES) dalam Tinjauan Hukum Islam". Al-Mawarid. Edisi 18. Tahun 2008;

Muzamil, Mawardi. "Persamaan Perkreditan Perbankan Konvensional dan Pembiayaan Perbankan Syariah". Jurnal Hukum. Vol. 15 No. 3. April 2004. Yogyakarta; FH UII;
Pane, Erine. "Reksadana Syariah dalam Perspektif Hukum ekonomi". Jurnal kajian Hukum Al Adalah. Vol. 7 No. 2. Desember 2008;

Rahardjo, Sajipto. 2007. Menggagas Hukum Progresif. Semarang : Pustaka Pelajar dan IAIN Walisongo;

Simatupang, Taufik H. "Hukum dan Pembangunan Ekonomi”. Jurnal Ilmiah Ke-bijakan Hukum. Vol. 1 No. 1. April 2007;

Suwandi. "Pembangunan Hukum Perbankan Syariah di Indonesia". Jurnal Hukum Islam El Qisth Vol. 3 No. 2. Maret 2007;

Wiyanti, Diana. "Pasar Modal Syariah dalam Kajian Hukum Bisnis". Jurnal Kajian Hukum al Adalah. Vol. 7 No. 2. Desember 2008. 